\title{
Front Matter: Volume 10044
}

, "Front Matter: Volume 10044," Proc. SPIE 10044, Lasers in Dentistry XXIII, 1004401 (12 April 2017); doi: 10.1117/12.2268493

SPIE. Event: SPIE BiOS, 2017, San Francisco, California, United States 


\section{PROGRESS IN BIOMEDICAL OPTICS AND IMAGING}

\section{Lasers in Dentistry XXIII}

Peter Rechmann

Daniel Fried

Editors

29 January 2017

San Francisco, California, United States

Sponsored and Published by

SPIE 
The papers included in this volume were part of the technical conference cited on the cover and title page. Papers were selected and subject to review by the editors and conference program committee. Some conference presentations may not be available for publication. The papers published in these proceedings reflect the work and thoughts of the authors and are published herein as submitted. The publisher is not responsible for the validity of the information or for any outcomes resulting from reliance thereon.

Please use the following format to cite material from these proceedings:

Author(s), "Title of Paper," in Lasers in Dentistry XXIII, edited by Peter Rechmann, Daniel Fried, Proceedings of SPIE Vol. 10044 (SPIE, Bellingham, WA, 2017) Seven-digit Article CID Number.

ISSN: 1605-7422

ISSN: 2410-9045 (electronic)

ISBN: 9781510605299

ISBN: 9781510605305 (electronic)

Published by

SPIE

P.O. Box 10, Bellingham, Washington 98227-0010 USA

Telephone +1 3606763290 (Pacific Time) · Fax +1 3606471445

SPIE.org

Copyright @ 2017 , Society of Photo-Optical Instrumentation Engineers.

Copying of material in this book for internal or personal use, or for the internal or personal use of specific clients, beyond the fair use provisions granted by the U.S. Copyright Law is authorized by SPIE subject to payment of copying fees. The Transactional Reporting Service base fee for this volume is $\$ 18.00$ per article (or portion thereof), which should be paid directly to the Copyright Clearance Center (CCC), 222 Rosewood Drive, Danvers, MA 01923. Payment may also be made electronically through CCC Online at copyright.com. Other copying for republication, resale, advertising or promotion, or any form of systematic or multiple reproduction of any material in this book is prohibited except with permission in writing from the publisher. The CCC fee code is 1605 $7422 / 17 / \$ 18.00$.

Printed in the United States of America.

Publication of record for individual papers is online in the SPIE Digital Library.

\section{SPIE. DIGITAL \\ SPIEDigitalLibrary.org}

Paper Numbering: Proceedings of SPIE follow an e-First publication model, with papers published first online and then in print. Papers are published as they are submitted and meet publication criteria. A unique citation identifier (CID) number is assigned to each article at the time of the first publication. Utilization of CIDs allows articles to be fully citable as soon as they are published online, and connects the same identifier to all online, print, and electronic versions of the publication. SPIE uses a seven-digit CID article numbering system in which:

- The first five digits correspond to the SPIE volume number.

- The last two digits indicate publication order within the volume using a Base 36 numbering system employing both numerals and letters. These two-number sets start with 00, 01, 02, 03, 04, $05,06,07,08,09,0 A, 0 B \ldots$. 0Z, followed by 10-1Z, 20-2Z, etc.

The CID Number appears on each page of the manuscript. The complete citation is used on the first page, and an abbreviated version on subsequent pages. 


\title{
Contents
}

\author{
$\checkmark$ Authors \\ vii Conference Committee
}

OCT IN ORAL TISSUES AND BIOFILM, NIR IMAGING

1004406 Characterization of human oral tissues based on quantitative analysis of optical coherence tomography images [10044-5]

1004407 Assessment of cavitation in artificial approximal dental lesions with near-IR imaging [10044-6]

1004408 Near-infrared imaging of enamel hypomineralization due to developmental defects [10044-7]

1004409 Assessing the dynamic biofilm removal of sulfonated phenolics using CP-OCT [10044-8]

\section{LASERS IN DISINFECTION, HARD TISSUE ABLATION AND CLINICAL CARIES MONITORING}

10044 OA Compact Nd:YAG laser operating at 1.06, 1.32, and $1.44 \mu \mathrm{m}$ for dental caries effective disinfection [10044-9]

$10044 \mathrm{OB}$ Investigations on the potential of a novel diode pumped Er:YAG laser system at high mean laser power for hard tissue preparation in dentistry [10044-10]

10044 OC Selective laser ablation of carious lesions using simultaneous scanned near-IR diode and $\mathrm{CO}_{2}$ lasers [10044-11]

10044 OD Developing laser-based therapy monitoring of early caries in pediatric dental settings [10044-12]

LASERS IN COMPOSITE REMOVAL, PULP VITALITY MEASUREMENTS, BOND STRENGTH AND ACID RESISTANCE

10044 OE Automated ablation of dental composite using an IR pulsed laser coupled to a plume emission spectral feedback system [10044-13]

10044 OF Laser Doppler pulp vitality measurements: simulation and measurement [10044-14]

$10044 \mathrm{OH}$ Influence of multi-wavelength laser irradiation of enamel and dentin surfaces on surface morphology and permeability [10044-16] 
$10044 \mathrm{Ol}$ Selective removal of natural caries lesions from dentin and tooth occlusal surfaces using a diode-pumped Er:YAG laser [10044-17]

$10044 \mathrm{~J} \quad H i g h$-contrast reflectance imaging of composite restorations color-matched to tooth structure at 1000-2300-nm [10044-18]

10044 OK Assessment of radicular dentin permeability after irradiation with $\mathrm{CO}_{2}$ laser and endodontic irrigation treatments with thermal imaging [10044-19]

$10044 \mathrm{OL}$ Synergistic effect of fluoride and laser irradiation for the inhibition of the demineralization of dental enamel [10044-20]

10044 OM Optical changes of dentin in the near-IR as a function of mineral content [10044-21] 


\section{Authors}

Numbers in the index correspond to the last two digits of the seven-digit citation identifier (CID) article numbering system used in Proceedings of SPIE. The first five digits reflect the volume number. Base 36 numbering is employed for the last two digits and indicates the order of articles within the volume. Numbers start with 00, 01, 02, 03, 04, 05, 06, 07, 08, 09, 0A, 0B...0Z, followed by 10-1Z, 20-2Z, etc.

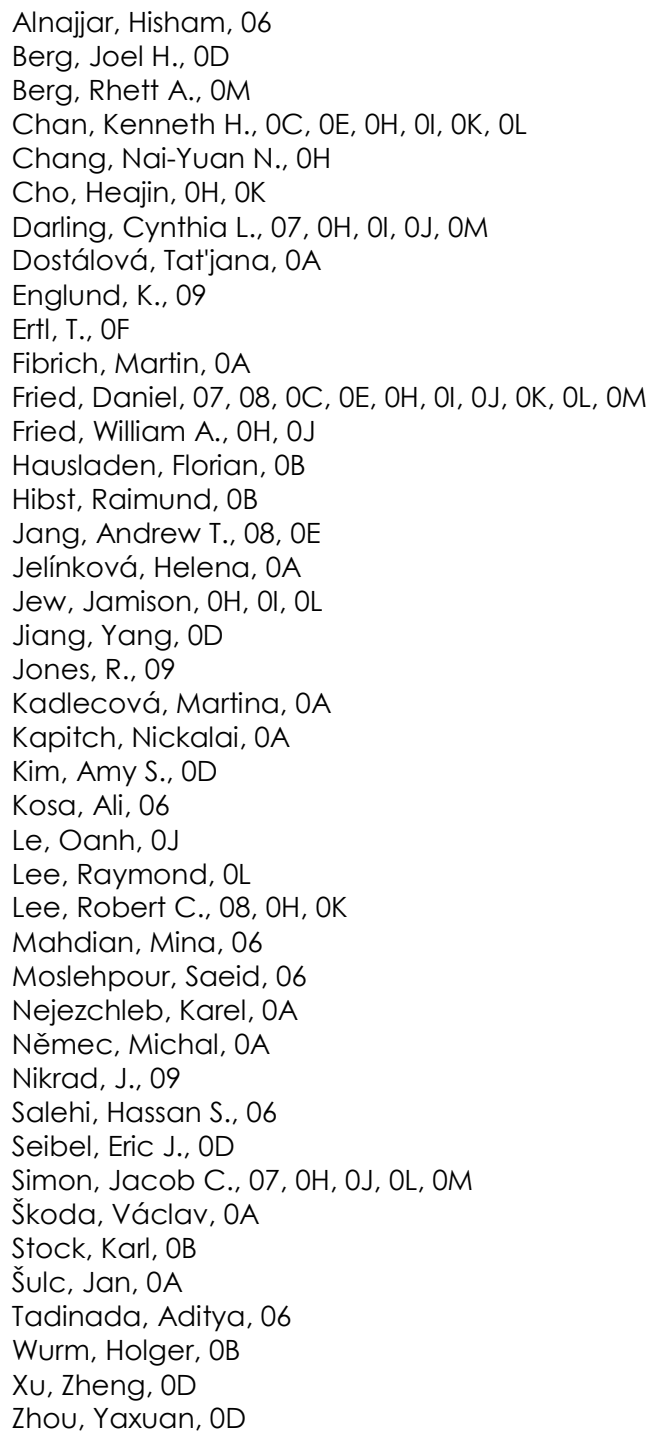


Proc. of SPIE Vol. 10044 1004401-6

Downloaded From: https://www.spiedigitallibrary.org/conference-proceedings-of-spie on 25 Apr 2023 Terms of Use: https://www.spiedigitallibrary.org/terms-of-use 


\title{
Conference Committee
}

\author{
Symposium Chairs
}

James G. Fujimoto, Massachusetts Institute of Technology

(United States)

R. Rox Anderson, Wellman Center for Photomedicine, Massachusetts General Hospital (United States) and Harvard School of Medicine (United States)

Program Track Chair:

Brian Jet-Fei Wong, Beckman Laser Institute and Medical Clinic (United States)

\section{Conference Chairs}

Peter Rechmann, University of California, San Francisco

(United States)

Daniel Fried, University of California, San Francisco (United States)

Conference Program Committee

Gregory B. Altshuler, Palomar Medical Technologies, Inc.

(United States)

Tatjána Dostálová, Charles University in Prague (Czech Republic)

Thomas Ertl, Universität Stuttgart (Germany)

David M. Harris, Bio-Medical Consultants, Inc. (United States)

Jörg Meister, Universitätsklinikum Bonn (Germany)

Eric J. Seibel, University of Washington (United States)

Session Chairs

1 OCT in Dental Tissues and Early Caries Detection

Peter Rechmann, University of California, San Francisco (United States)

2 OCT in Oral Tissues and Biofilm, NIR Imaging

Daniel Fried, University of California, San Francisco (United States)

3 Lasers in Disinfection, Hard Tissue Ablation and Clinical Caries

Monitoring

Peter Rechmann, University of California, San Francisco

(United States) 
4 Lasers in Composite Removal, Pulp Vitality Measurements, Bond Strength and Acid Resistance

Daniel Fried, University of California, San Francisco (United States) 